\title{
PENGEMBANGAN MEDIA LABORATORIUM VIRTUAL MODEL 4D PADA MATA KULIAH FISIKA
}

\author{
Listia Utami ${ }^{1, \mathrm{a}}$, Amran Amiruddin ${ }^{2, \mathrm{~b}}$ \\ ${ }^{1,2}$ Program Studi Teknik Komputer Sekolah Tinggi Manajemen Informatika dan Komputer AKBA \\ e-mail: ${ }^{\mathrm{a}}$ listia@akba.ac.id, ${ }^{\mathrm{b}}$ amran@akba.ac.id
}

\begin{abstract}
Abstrak
Berawal dari berbagai persoalan mahasiswa yang tidak memahami konsep dasar materi pada mata kuliah fisika terutama yang berkaitan dengan laboratorium sehingga mempengaruhi nilai pada mata kuliah fisika. Persoalan tidak tersedianya ruang dan peralatan laboratorium fisika di STMIK AKBA juga menjadi permasalahan, untuk mengajarkan konsep-kosep fisika yang bersifat abstrak diperlukan simulasi langsung untuk member pemahaman kepada mahasiswa. STMIK AKBA memiliki tiga laboratorium computer dengan spesifikasi yang memadai, dimana computer dapat membuat konsepkonsep yang abstrak menjadi konkret melalui media dengan visualisasi statis maupun dengan visualisasi dinamis (animasi). Selain itu, computer dapat membuat suatu konsep lebih menarik sehingga menambah motivasi untuk mempelajari dan memahaminya. Penelitian ini bertujuan untuk melakukan pengembangan media laboratorium virtual memudahkan mahasiswa STMIK AKBA dalam mempelajari konsep-konsep dasar fisika sehingga memotivasi mahasiswa dalam belajar. Jenis penelitian ini adalah penelitian pengembangan, menggunakan model pengembanganseperti yang dikembangkan oleh Thiagarajan yakni melalui 4D-Model (Define, Design, Develop, and Disseminate). Media tutorial untuk pembelajaran dibangun dengan menggunakan software Lectora, Multism, Microsoft Power Point 2010, Camtasia Studio 6.0, Adobe Photoshop CS4 dan Nero 8.0.. Penelitian ini berjenis kuantitatif, dimana media yang dihasilkan akan diuji kevalidan, kepraktisan dan keefektifan media. Melalui penelitian ini diharapkan dapat menciptakan suatu media pembelajaran berupa Laboratorium virtual yang dapat membantu mahasiswa memahami konsepkonsep dasar fisika.
\end{abstract}

Kata kunci: laboratorium virtual, Model 4D, Pembelajaran Fisika

\section{DEVELOPMENT OF A VIRTUAL LABORATORY MEDIA WITH 4D MODEL IN PHYSICS COURSE}

\begin{abstract}
Starting from various problems students who did not understand the basic concepts of material in physics courses, especially those related to laboratories, thus affecting the learning outcomes of physics courses. The problem of the unavailability of space and physical laboratory equipment in STMIK AKBA is also a problem, in order to teach the concepts of physics which are abstract in nature, a direct simulation is needed to give understanding to students. STMIK AKBA has three computer laboratories with adequate specifications, where computers can illustrate abstract concepts into concrete through the media with static visualization and with dynamic visualization (animation). In addition, computers can make a concept more attractive so that it adds motivation to learn and understand it. This study aims to develop virtual laboratory media to make it easier for STMIK AKBA students to learn basic physics concepts so as to motivate students in learning. This type of research is development research, using a development model like the one developed by Thiagarajan namely through 4D-Models (Define, Design, Develop, and Disseminate). Tutorial media for learning are built using Lectora, Multism, Microsoft Power Point 2010, Camtasia Studio 6.0, Adobe Photoshop CS4 and Nero 8.0 software. This research is a quantitative type, where the media produced will be tested for validity, practicality and media effectiveness. Through this research is expected to create a learning media in the form of a virtual laboratory that can help students understand the basic concepts of physics.
\end{abstract}

Keywords: a virtual laboratory, 4D model, Physics Instruction 


\section{PENDAHULUAN}

Pendidikan Ilmu Pengetahuan Alam (IPA) merupakan salah satu cabang pendidikan yang membahas tentang fenomena alam secara sistematis. Salah satu cabang pendidikan IPA yang sangat diperlukan dalam perkembangan ilmu pengetahuan dan teknologi adalah ilmu Fisika. Menyadari betapa pentingnya peranan Fisika dalam menjawab persoalan tantangan global dan kemajuan IPTEK, dituntut perubahan kearah yang lebih baik pada pembelajaran Fisika dengan berbagai variasi strategi dan metode pembelajaran yang efektif. Menjadi persoalan beberapa perguruan tinggi swasta masih kurang tersedianya ruang praktikum.

Salah satu perguruan tinggi swasta yaitu STMIK AKBA yang memiliki fasilitas prasarana tiga ruangan laboratorium Software, dan satu ruangan laboratorium Hardware. Menjadi persoalan pada mata kuliah fisika yang merupakan mata kuliah pada program studi teknik informatika yang menjelaskan mengenai konsep kinematika, dinamika, kelistrikan, osilasi dan gelombang membutuhkan praktikum sehingga mahasiswa dapat memahami konsep-konsep dasar tersebut. Namun di STMIK AKBA belum disediakan laboratorium dan alat-alat laboratorium khusus fisika.

Konsep Laboratorium Virtual (Virtual Laboratory) dapat dibedakan menjadi dua konsep utama, yaitu: (1) konstelasi percobaan diganti dengan model komputer. Penelitian itu dilakukan dalam bentuk simulasi. Simulasi yang mewakili percobaan laboratorium riil dalam bentuk semirip mungkin disebut virtual labs. (2) eksperimen laboratorium dapat disebut virtual ketika percobaan dikendalikan tidak dengan manipulasi langsung dari peralatan laboratorium, tetapi melalui komputer, yang dihubungkan keperalatan laboratorium yang sebenarnya melalui jaringan.

Berdasarkan latar belakang yang telah dikemukakan maka, peneliti merumuskan yaitu Media Presentase pembelajaran fisika laboratorium virtual dan Media tutorial untuk pembelajaranman diri peserta didik yang untuk mencapai tujuan penelitian yang diharapkan berdasarkan pemanfaatan waktu penelitian, makaterdapatbatasanMaterifisika yang akan di kembangkan pada laboratorium virtual yaitu; pengukuran, listrik statis dan listrik dinamis.

\section{TINJAUAN PUSTAKA}

Media adalah mode stimulus interaksi manusia, realita, gambar, symbol tulisan, suara (Rown tree). Media adalah Software berikut Hardware yang digunakan dalam komunikasi pembelajaran (Heidt). Media pembelajaran meliputi segala sesuatu yang dapat membantu pengajar dalam menyampaikan materi pembelajaran, sehingga dapat meningkatkan motivasi, daya pikir, dan pemahaman mahasiswa terhadap materi pembelajaran yang sedang dibahas atau mempertahankan perhatian peserta terhadap materi yang sedang dibahas. (Munir, 2008)

Perkembangan teknologi informasi menyediakan kesempatan untuk membangun dan menggunakan animasi computer untuk pembelajaran yang berorientasi pada representasi mikroskopik. Hal ini dapat diwujudkan dengan bantuan animasi computer karena animasi computer dapat memvisualisasikan proses-proses abstrak yang mustahil dilihat atau dibayangkan. Konsep virtual laboratory dapat dibedakan menjadi dua konsep utama, 
yaitu: (1) konstelasi percobaan diganti dengan model komputer. Penelitian itu dilakukan dalam bentuk simulasi. Simulasi yang mewakili percobaan laboratorium riil dalam bentuk semirip mungkin disebut virtual labs. (2) eksperimen laboratorium dapat disebut virtual ketika percobaan dikendalikan tidak dengan manipulasi langsung dari peralatan laboratorium, tetapi melalui komputer, yang dihubungkan ke peralatan laboratorium yang sebenarnya melalui jaringan. (Darmawan, 2012 )

Lectora adalah perangkat lunak Authoring Tool untuk pengembangan konten e-learning yang dikembangkan oleh Trivantis Corporation. Lectora digunakan untuk membuat website, konten e-learning interaktif, dan presentasi. Lectora juga memungkinkan untuk mengkonversi presentasi Microsoft Power Point ke konten elearning. Konten yang dikembangkandenganperangkatlunakLector adapatdipublikasikankeberbagai output seperti HTML, single file executable, CDROM, maupunstandar e-learning. Lectorakompatibeldenganberbagaisistemma najemenpembelajaran. (Rusman, 2012)

Multism adalah program simulasi yang digunakan untuk melakukan simulasi cara kerja sebuah rangkaian elektronika. Program multisim pertama kali dibuat oleh perusahaan yang bernama Electronics Workbench yang merupakan bagian dari perusahaan National Instruments dan pertama kali dikenalkan dengan nama Electronics Instruments yang pada saat itu ditujukan sebagai alat bantu pengajaran di dalam bidang elektronika. (Rusman, 2012)

Model pengembangan 4-D (Four D) merupakan model pengembangan perangkat pembelajaran. Model inidikembangkanoleh S. Thiagarajan, Dorothy S. Semmel, dan Melvyn I. Semmel. Model pengembangan
4D terdiriatas 4 tahaputamayaitu: (1) Define (Pembatasan), (2) Design (Perancangan),(3) Develop (Pengembangan) dan Disseminate (Penyebaran), atau diadaptasi Model 4D, yaitu Pendefinisian, Perancangan, Pengembangan, dan Penyebaran. (Trianto, 2012)

\section{METODE}

\section{Jenis Penelitian}

Jenis penelitian ini adalah penelitian pengembangan, menggunakan model pengembangan seperti yang dikembangkan oleh Thiagarajan yakni melalui 4D-Model (Define, Design, Develop, and Disseminate). Keempat D dalam 4D-Model merupakan tahap-tahap dalam pengembangan perangkat pembelajaran, akan tetapi pada penelitian ini akan diadopsi sampai pada D yang ketiga, yakni hingga tahap develop (pengembangan).

\section{Waktu dan Tempat Penelitian}

Penelitian dilaksanakan di STMIK AKBA yang beralamat di jalan Perintis kemerdekaan IX No. 75 Makassar. Adapun waktu penelitian direncanakan pada bulan April 2018 sampai bulan September 2018.

\section{Target/Subjek Penelitian}

Target/subjek penelitian (untuk penelitian kualitatif) atau populasi-sampel (untuk penelitian kuantitatif) perlu diurai dengan jelas dalam bagian ini. Perlu juga dituliskan teknik memperoleh subjek (penelitian kualitatif) dan atau teknik samplingnya (penelitian kuantitatif).

\section{Prosedur}

\section{Tahap Pendefinisian (define)}

Tujuan tahap ini adalah untuk menetapkan dan mendefinisikan syaratsyarat pembelajaran.Langkah-langkah tahap ini yaitu dilakukan analisis awal, analisis 
mahasiswa, analisis konsep, dan perumusan indikator pembelajaran.

\section{Analisis Awal}

Pada tahap ini, mengidentifikasi tujuan pembelajaran berupa kompetensi dasar mata kuliah fisika kemudian menganalisis masalah-masalah mendasar yang dihadapi oleh mahasiswa dan perlu dijadikan sebagai bahan pertimbangan dalam pengembangan media pembelajaran.

2. Analisis Mahasiswa

Mengidentifikasi kemampuan dan karakteristik awal mahasiswa yang berkaitan dengan materi fisika seperti pengukuran, kelistrikan. Pengidentifikasian dilakukan dengan memberikan beberapa materi yang telah mahasiswa pelajari sebelumnya dan berkaitan dengan mata kuliah fisika. Identifikasi karakteristik peserta didik dalam penelitian ini menyangkut pengetahuan awal peserta didik dan karakteristik umum peserta didik.

3. Analisis Tugas

Analisis tugas adalah analisis prosedural yang dilakukan dengan mengidentifikasi tahap-tahap penyelesaian tugas untuk mencapai kompetensi. Pada tahap ini dilakukan analisis prosedural yang mencakup kegiatan mahasiswa selama praktikum.

\section{Analisis Konsep}

Analisis konsep dilakukan dengan mengidentifikasi konsep-konsep utama yang disusun secara sistematis dalam peta konsep dengan materi dengan terlebih dahulu memperkenalkan pre lab dan pasca lab.

5.Perumusan Indikator Pembelajaran

Tahap perumusan tahap ini bertujuan untuk merumuskan indikator pembelajaran.

\section{Tahap Perancangan (design)}

Tujuan tahap ini adalah untuk merancang media pembelajaran. Proses pendesainan ini adalah sebagai berikut:
1. Desain awal media pembelajaran

Langkah-langkah yang dilakukan dalam desain media pembelajaran adalah sebagai berikut: a. Menyiapkan software untuk pengembangan media presentasi dan tutorial. Secara spesifikasi produk tersebut adalah :

1) Perangkat lunak slide pembelajaran di kelas. Perangkat lunak untuk pembelajaran di kelas dibangun dengan menggunakan software multisim, Lectora, Macromedia Flash CS4, Microsoft Power Point 2007, Camtasia Studio 6.0, Adobe Photoshop CS4, dan Microsoft Word 2007. Perangkat lunak yang dihasilkan diperuntukkan untuk dipergunakan dosen saat membelajarkan mahasiswa di kelas. Isi perangkat lunak tersebut berupa file materi pelajaran dan laboratorium virtual.

2) Perangkat lunak pembelajaran mandiri untuk mahasiswa. Perangkat lunak untuk pembelajaran mandiri peserta didik dibangun dengan menggunakan software Microsoft Power Point 2007, Camtasia Studio 6.0, Adobe Photoshop CS4 dan nero 8.0. Perangkat lunak yang dihasilkan diperuntukkan untuk dipergunakan mahasiswa belajar secara mandiri.

2. Pembuatan flowchart/diagram alir program.Diagram Alir atau Flowchart menggambarkan alur proses atau sistematika dari multimedia pembelajaran yang akan dikembangkan.

\section{Tahap Pengembangan (develop)}

Tujuan tahap ini adalah menyempurnakan media yang telah dibuat agar lebih baik melalui revisi berdasarkan saran-saran para dosen ahli. Tahap ini meliputi:

1. Validasi

Validasi media pembelajaran dilakukan oleh ahli media untuk mengetahui kevalidan media dari segi aspek kualitas tampilan dan daya tarik. Validasi oleh ahli 
materi untuk mengetahui kevalidan perangkat pembelajaran dari segi materi, kebahasaan, dan penyajian. Selain itu, juga dilakukan validasi perangkat pembelajaran meliputi Rencana Pembelajaran (RP) dan Lembar Praktikum.

\section{Uji Coba Terbatas}

Uji coba terbatas akan dilakukan mahasiswa satu kelas program studi teknik informatika yang mengikuti mata kuliah fisika. Hasil uji coba terbatas ini adalah penilaian mahasiswa terhadap media pembelajaran yang dikembangkan.

\section{Pengemasan}

Setelah dilakukan analisis pada tahap uji coba, selanjutnya diperoleh draft final media pembelajaran dan dibuat dalam bentuk CD autorun.

\section{Data, Intrumen, Teknik Pengumpulan Data, dan Teknik Analisis Data}

Untuk memperoleh informasi tentang kriteria kevalidan, kepraktisan dan keefektifan media yang dihasilkan, maka perlu dikembangkan instrumen. Instrumeninstrumen tersebut adalah sebagai berikut :

1.Lembar validasi media pembelajaran digunakan untuk memperoleh informasi tentang kualitas media pembelajaran berdasarkan penilaian beberapa validator. Validasi akan memberikan informasi yang akan digunakan sebagai masukan dalam merevisi media yang dikembangkan sehingga layak untuk digunakan. Pada lembar validasi, validator menuliskan penilaian terhadap media yang dikembangkan.

2.Respon mahasiswa terhadap proses pembelajaran yang menggunakan media untuk mengetahui kepraktisan media pembelajaran yang dikembangkan. Respon mahasiswa meliputi pendapat/tanggapan mahasiswa terhadap proses pembelajaran yang menggunakan media. Selain itu untuk melihat pendapat/respon mahasiswa terhadap kemudahan dalam memahami materi. Data respon mahasiswa diperoleh melalui angket. Angket tersebut diisi oleh peserta didik setelah mengikuti pembelajaran.

3. Lembar pengamatan aktivitas mahasiswa selama kegiatan pembelajaran berlangsung untuk melihat keefektifan media yang dikembangkan. Data aktivitas mahasiswa selama kegiatan pembelajaran diperoleh melalui observasi di kelas. Instrumen yang digunakan adalah lembar pengamatan aktivitas mahasiswa selama kegiatan pembelajaran.

\section{HASIL DAN DISKUSI}

\section{Hasil validasi media pembelajaran}

Aspek-aspek yang diperhatikan dalam memvalidasi media pembelajaran model presentase adalah kualitas tampilan dan daya tarik. Hasil validasi dari ahli dapat dirangkum pada Tabel 1 di bawah ini:

Tabel 1 Rangkuman hasil validasi media pembelajaran model presentase

\begin{tabular}{clcc}
\hline No & Aspek penilaian & $\bar{x}$ & Ket \\
\hline 1 & $\begin{array}{l}\text { Kualitas } \\
\text { Tampilan }\end{array}$ & 3,50 & $\begin{array}{c}\text { Sangat } \\
\text { valid }\end{array}$ \\
2 & Daya Tarik & 3,37 & Valid \\
\hline & $\begin{array}{c}\text { Rata-rata } \\
\text { penilaian total }\end{array}$ & 3,43 & Valid \\
\hline
\end{tabular}

Gambar 1. Diagram batang hasil validasi media pembelajaran model presentase

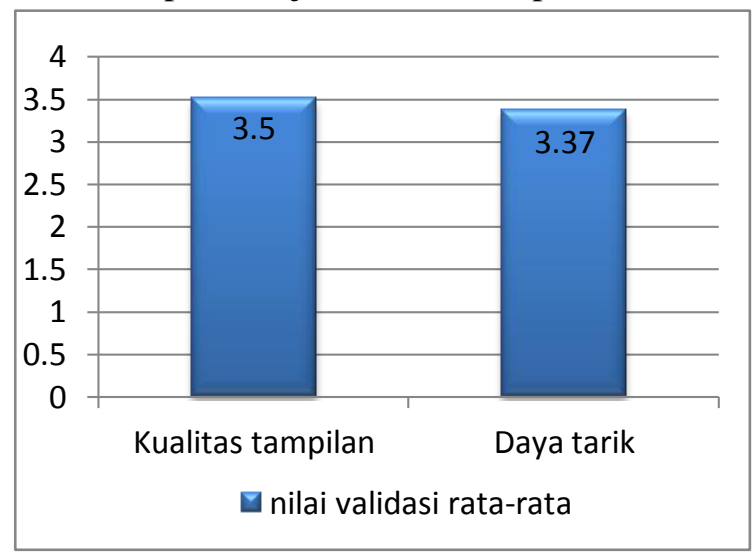


Nilai rata-rata total kevalidan pada media pembelajaran model presentase diperoleh $\bar{x}=$ 3,43 . Berdasarkan kriteria kevalidan, nilai ini termasuk dalam kategori"valid" karena berada

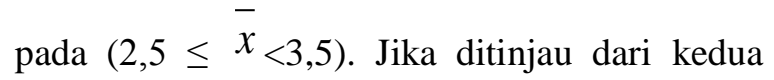
aspek di atas secara keseluruhan, maka media pembelajaran model presentase ini dapat dinyatakan "valid".

\section{Hasil validasi Rencana Pembelajaran}

Aspek-aspek yang diperhatikan dalam memvalidasi Rencana Pembelajaran adalah: format, materi, bahasa, waktu, dan metode sajian. Hasil validasi dari ahli dapat dirangkum pada Tabel 2. di bawah ini:

Tabel 2. Rangkuman hasil validasi

Rencana Pembelajaran

\begin{tabular}{clcc}
\hline No & \multicolumn{1}{c}{ Aspek penilaian } & $\bar{x}$ & Ket \\
\hline 1 & $\begin{array}{l}\text { Format Rencana } \\
\text { Pembelajaran }\end{array}$ & 3,17 & Valid \\
2 & $\begin{array}{l}\text { Materi (isi) yang } \\
\text { disajikan }\end{array}$ & 3,50 & Sangat valid \\
3 & Bahasa & 3 & Valid \\
4 & Waktu & 3,50 & Sangat valid \\
5 & Metode sajian & 2,60 & Valid \\
\hline & Rata-rata penilaian \\
$\quad$ total & 3,15 & Valid \\
\hline
\end{tabular}

Gambar 2 Diagram batang hasil validasi Rencana Pembelajaran

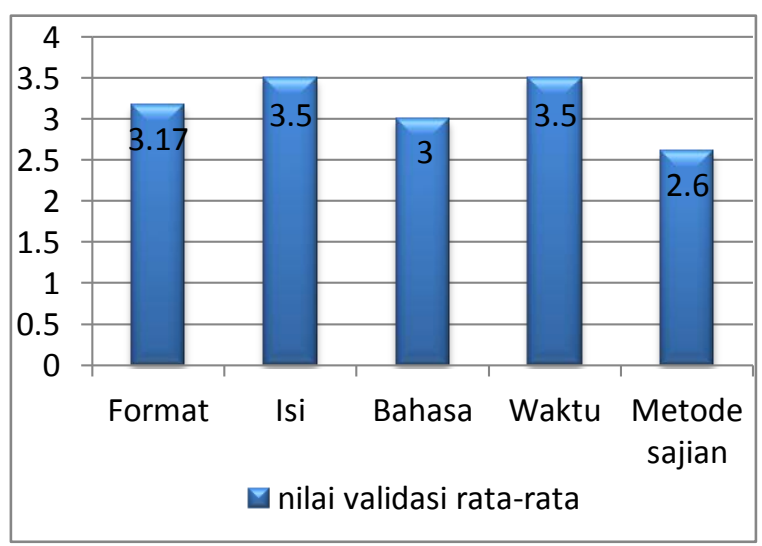

Nilai rata-rata total kevalidan pada RencanaPembelajaran diperoleh $\quad \bar{x}=3,15$. Berdasarkan kriteria kevalidan, nilai ini termasuk dalam kategori "valid" karena berada pada $(2,5 \leq \bar{x}<3,5)$. Jika ditinjau dari kelima aspek di atas secara keseluruhan, maka Rencana Pembelajaran ini dapat dinyatakan memenuhi kriteria "valid".

\section{Hasil validasi LembarKerja}

Dalam menyusun Lembar Kerja, beberapa aspek yang perlu diperhatikan dalam memvalidasi perangkat yaitu: format, isi, bahasa/tulisandanmanfaatLembarKerja. Hasil validasi secara lengkap dapat dilihat pada tabel 3 berikut:

Tabel 3 Rangkuman hasil validasi LembarKerja

\begin{tabular}{clcc}
\hline No & Aspek penilaian & $\bar{x}$ & Ket \\
\hline 1 & Format & 3,25 & Valid \\
2 & Isi & 3,21 & Valid \\
3 & Bahasa/Tulisan & 3 & Valid \\
4 & Manfaat LKPD & 3,50 & Sangat valid \\
\hline & Rata-rata penilaian & 3,24 & Valid \\
& total & & \\
\hline
\end{tabular}

Gambar 3 Diagram batang hasil validasi Lembar Kerja

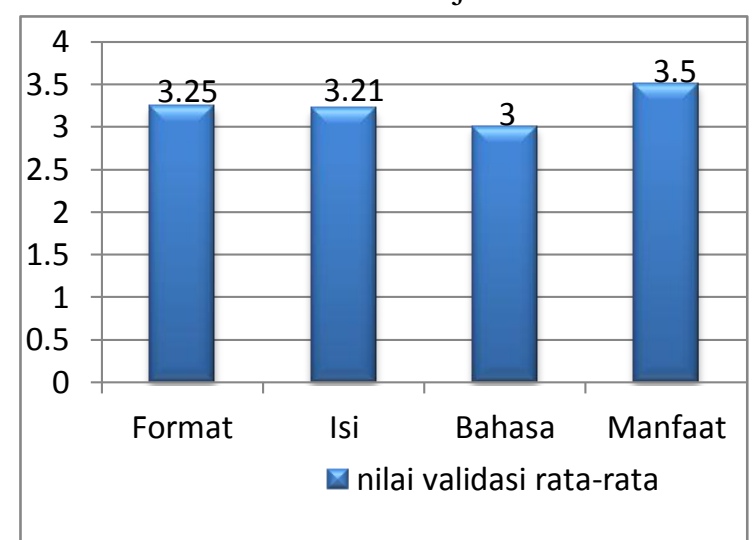

Untuk nilai rata-rata total kevalidan Lembar Kerja diperoleh $\bar{x}=3,24$ dan berdasarkan kriteria kevalidan, nilai ini termasuk dalam kategori"valid" karena berada pada $(2,5 \leq \bar{x}<3,5)$. Jika ditinjau dari keempat aspek di atas secara keseluruhan, maka Lembar Kerja ini dapat dinyatakan memenuhi kriteria kevalidan sehingga dapat digunakan dalam melakukan penelitian. 
Beberapa kendala yang dihadapi dalam pengembangan media pembelajaran ini adalah adanya beberapa software yang digunakan belum memiliki lisensi (versi demo) sehingga ada beberapa fitur dari software tersebut yang belum bias digunakan. Begitu pula pada pembuatan video tutorial dengan tata suara/intonasi dari narasi audio yang masih belum sempurna mengingat keterbatasan peneliti selama mereka menarasi audio tersebut. Kendala lain adalah pada pengistalan software pada komputer/laptop yaitu masih ada beberapa siswa yang belum bisa melakukan penginstalan software sehingga harus dibantu oleh peneliti sendiri.

Adapun kendala pada saat melakukan uji coba media pembelajaran ini adalah ketersediaan perangkat komputer/laptop yang belum memadai sehingga peserta didik dibagi menjadi beberapa kelompok. Sebaiknya uji coba dilakukan pada laboratorium computer sehingga setiap peserta didik dapat melakukan percobaan virtual dengan lebih efektif.

\section{SIMPULAN DAN SARAN}

\section{Simpulan}

1. Media Presentase pembelajaran fisika laboratorium virtual dan media tutorial untuk pembelajaran mandiri peserta didik yang dikembangkan telah memenuhi kriteria valid berdasarkan penilaian validator terhadap kualitas tampilan dan daya tarik media, praktis berdasarkan efisiensi pembelajaran dan respon peserta didik, serta efektif berdasarkan hasil belajar.

2. Rencana Pelaksanaan Pembelajaran dan Lembar Kerja Peserta Didik yang dikembangkan telah memenuhi kriteria valid, praktis dan efektif.

\section{Saran}

Berdasarkan penelitian yang dilakukan maka beberapa hal yang disarankan sebagai berikut:
1. Dalam pembuatan media pembelajaran, disarankan menggunakan software yang sudah memiliki lisensi (full version) agar semua fitur-fitur dari software tersebut dapat digunakan denganbaik.

2. Penelitian pengembangan ini sudah menghasilkan media pembelajaran yang valid, praktis, dan efektif. Oleh karena itu, disarankan kepada guru fisika untuk dapat menggunakan media pembelajaran ini pada materi listrikdinamis.

3. Bagi peneliti yang berminat melakukan penelitian pengembangan media pembelajaranagar mencermati segala kelemahan dan keterbatasan penelitian ini, sehingga penelitian yang dilakukan dapat menghasilkan media pembelajaran yang lebih valid, praktis, dan efektif.

4. Penelitian lanjutan diperlukan untuk mengetahui sejauh mana peningkatan pemahamankonsep, motivasi, dan prestasi belajar peserta didik dengan menggunakan media pembelajaran ini.

\section{UCAPAN TERIMA KASIH}

Ucapan Terima kasih kepada DRPM KEMENRISTEKDIKTI yang telah memberi dukungan finacial terhadap penelitian ini.

\section{DAFTAR PUSTAKA}

[1] Arikunto, S. (2006). Prosedur Penelitian: Suatu Pendekatan Praktik. Jakarta: Rineka Cipta.

[2] Darmawan, D. (2012). Teknologi Pembelajaran. Bandung: PT Remaja Rosdakarya.

[3] Dimyati. 2006. Belajar dan Pembelajaran. Jakarta: Rineka Cipta

[4] Elang Krisnadi. (2009). Rancangan Materi Pembelajaran Berbasis ICT. Disajikan dalam Workshop Pengembangan Materi Pembelajaran Berbasis ICT di FMIPA UNY pada tanggal 6 Agustus 2009. Online. 
[5] Eka, R. N. 2009. Pengembangan Pembelajaran Matematika Berbasis Web. Tesis. PPs UNM

[6] Gunawan. 2011. Repository Disertasi UPI: Pengembangan Model Virtual Laboratory Fisika Modern Untuk Meningkatkan Keterampilan Generik Sains dan Disposisi Berpikir Kritis Calon

Guru(online).(http://repository.upi.edu/ disertasiview.php?no_disertasi=91),dia kses tanggal 5 Desember 2012).

[7] Kanginan, Marthen. 2007. Fisika untuk SMA Kelas XII. Jakarta: Erlangga.

[8] Krane, Kenneth. 1992. Fisika Modern. Terjemahan oleh Hans J. Wospaktrik. 2008. Jakarta: Universitas Indonesia Press.
[9] Munir. 2008. Kurikulum Berbasis Informasi dan Komunikasi. Bandung: Alfabeta.

[10] Prawiradilaga, D. S. (2007). Mozaik Teknologi Pendidikan. Jakarta: Kencana Prenada Media Group.

[11] Riduwan. (2011). Skala Pengukuran Variabel-Variabel Penelitian. Bandung: Alfabeta.

[12] Rusman. 2011. Model-Model Pembelajaran. Jakarta: Rajawali Pers

[13] _. 2012. Belajar dan Pembelajaran Berbasis Komputer. Bandung: Alfabeta

[14] Sagala, Syaiful. 2005. Konsep dan Makna Pembelajaran. Bandung : Alfabeta. 